\title{
ANALISIS KEUNGGULAN KOMPARATIF USAHATANI KOPI DI KABUPATEN BOLAANG MONGONDOW MENGGUNAKAN POLICY ANALYSIS MATRIX (PAM)
}

\author{
Yolanda Pinky Ivanna Rori \\ Jelly R. D. Lumingk ewas \\ Melissa Lady Gisela Tarore
}

\begin{tabular}{ll}
\hline Naskah diterima melalui Website Jurnal Ilmiah agrisosioekonomi@unsrat.ac.id & $:$ Senin, 30 September 2019 \\
Disetujui diterbitkan & $:$ Kamis, 17 Oktober 2019 \\
\hline
\end{tabular}

\begin{abstract}
The research has been done in Bolaang Mongondow. The aim of the research are to know the comparative advantage of coffee in Bolaang Mongondow North Sulawesi which is analized by Domestic Resource Cost Ratio (DRCR) value and to know the input and output price changes and its impact to the coffee farming comparative advantage. The area of research is selected by purposive method in Bolaang-Mongondow Regencies which are the production centre of coffee. The primary data are collected through interview with 20 coffee farmers while the secondary data are gained from related institutions. Descriptive analysis using Policy Analysis Matrix (PAM) was implemented in the research to know the comparative advantage value. Sensitivity analysis is used to determine the impact of prices changing to Domestic Resource Cost Ratio (DRCR). The result shows that coffee farming in Bolaang Mongondow has a comparative advantage which is indicated by the value of DRCR 0,0791. Both Private and Social benefit value are profitable. The private benefit is Rp. 5.821.590 and social benefit is Rp. 5.525.338.
\end{abstract}

Keywords : Coffee, PAM, Comparative Advantage

\begin{abstract}
ABSTRAK
Penelitian tentang keunggulan komparatif ini dilaksanakan di Kabupaten Bolaang Mongondow Tujuan penelitian ini adalah untuk mengetahui apakah komoditas kopi yang diusahakan oleh petani di di Kabupaten Bolaang Mongondow memiliki keunggulan komparatif yang dicerminkan dengan nilai DRCR dan mengetahui dampak perubahan harga input dan output terhadap keunggulan komparatif. Daerah penelitian ditentukan secara sengaja (purposive) yaitu di Kabupaten Bolaang-Mongondow yang merupakan daerah sentra produksi tanaman kopi. Pengumpulan data primer menggunakan teknik wawancara sebanyak 20 petani kopi dan data sekunder diperoleh dari instansi yang terkait. Metode yang digunakan dalam penelitian ini adalah metode deskriptif dengan menggunakan Policy Analysis Matrix (PAM) untuk mengetahui nilai keunggulan komparatif. Hasil penelitian menunjukkan bahwa usahatani kopi di Kabupaten Bolaang Mongondow memiliki keunggulan komparatif yang ditunjukkan dengan nilai DRCR 0,0791. Secara privat dan sosial menguntungkan untuk diusahakan. Secara privat memberikan keuntungan Rp. 5.821.590 dan secara sosial Rp. 5.525.338.
\end{abstract}

Kata kunci : Kopi, PAM, Keunggulan Komparatif 


\section{PENDAHULUAN}

\section{Latar Belakang}

Salah satu sub sektor pertanian yang memegang peranan penting dalam pembangunan ekonomi di Indonesia adalah sub sektor perkebunan. Secara formal, perkebunan adalah usahatani yang mengusahakan tanaman perkebunan yang luasnya lebih dari 25 hektar. Jenis tanaman perkebunan umumnya adalah tanaman keras (kelapa, karet, kopi, sawit, teh dan kakao) sedangkan yang termasuk dalam tanaman setahun sangat sedikit (tebu dan tembakau).

Salah satu tanaman keras perkebunan adalah tanaman kopi. Kopi adalah salah satu jenis tanaman tropis yang dapat tumbuh dimana saja, terkecuali pada tempat-tempat yang terlalu tinggi dengan temperatus yang sangat tinggi atau daerah-daerah tandus yang memang tidak cocok bagi kehidupan tanaman.

Peran kopi dalam perekonomian menurut Soetriono (2010), yaitu sebagai penghasil devisa, sumber pendapatan petani, penghasil bahan baku industri, penciptaan lapangan kerja dan pengembangan wilayah. Hal ini dibuktikan dengan komoditas kopi yang dihasilkan oleh petani masih mempunyai daya saing ditingkat internasional. sehingga target produksi kopi yang tinggi menunjukan harapan ekspor terhadap perekonomian kopi di Indonesia juga tinggi.

Di Provinsi Sulawesi Utara terutama Kabupaten Bolaang Mongondow, kopi robusta merupakan komoditas yang menjadi salah satu komoditas unggulan daerah karena memiliki luas lahan dan produksi yang lebih besar dibandingkan daerah lainnya di Provinsi Sulwesi Utara. Namun dalam pengembangan usahatani kopi masih memiliki kelemahan karena banyak petani kopi yang mulai alih fungsi lahan ke tanaman yang lainnya. Kelemahan lainnya yaitu, teknik budidaya yang dilakukan dan alat-alat yang digunakan petani masih sederhana, modal yang dimiliki petani terbatas, dan tingkat pendidikan para petani yang masih rendah. Kelemahan tersebut menyebabkan pengembangan tanaman kopi robusta belum sesuai dengan anjuran yang seharusnya, sehingga menyebabkan masih rendahnya produksi yang dihasilkan.
Sebagai salah satu komoditas pertanian yang menjadi komoditas unggulan, usahatani kopi robusta sejauh ini belum diketahui daya saingnya secara keunggulan komparatif, untuk itu perlu dilakukan penelitian mengenai keunggulan komparatif komoditas kopi robusta. Suatu daerah dinyatakan memiliki keunggulan komparatif apabila daerah tersebut mampu memproduksi barang dan jasa lebih banyak dengan biaya yang lebih efisien dari daerah lain. Menurut Mantau (2009) Keunggulan komparatif memiliki dua pengertian. Pertama, pengertian keunggulan komparatif mengenai efisiensi produksi yang membandingkan antara dua atau lebih negara-negara yang melakukan perdagangan. Kedua, pengertian keunggulan komparatif pada efisiensi dari berbagai jenis produksi di dalam ekonomi domestik yang dibandingkan pada pendapatan. Pada penelitian ini keunggulan komparatif merujuk pada efisiensi ekonomi domestik yang dihitung berdasarkan harga sosial atau harga internasional.

Pengukuran keunggulan komparatif menggunakan pendekatan Policy Analysis Matrix (PAM). Tabel PAM, selain digunakan untuk mengetahui keunggulan komparatif juga digunakan untuk mengetahui penyimpangan (divergensi) serta proteksi pemerintah.

\section{Rumusan Masalah}

Secara garis besar, permasalahan yang akan diuraikan lebih lanjut adalah sebagai berikut:

1. Apakah Kopi di Kabupaten Bolaang Mongondow memiliki keunggulan komparatif?

2. Bagaimana dampak perubahan harga input dan output terhadap keunggulan komparatif?

\section{Tujuan penelitian}

Tujuan penelitian ini antara lain:

1. Untuk menganalisis keunggulan komparatif usahatani kopi

2. Untuk mengetahui dampak perubahan harga input dan output terhadap keunggulan komparatif. 


\section{Manfaat Penelitian}

Manfaat dari penelitian ini adalah

1. Sebagai bahan informasi bagi petani kopi di Kabupaten Bolaang Mongondow sehingga dapat lebih optimal dalam pengembangan usahatani kopi.

2. Sebagai bahan pertimbangan dan masukan bagi para stakeholder dalam mengambil keputusan dan merumuskan kebijakan yang berkaitan dengan komoditi kopi.

3. Sebagai bahan referensi bagi penelitian serupa atau selanjutnya yang berkaitan dengan keunggulan komparatif.

\section{METODE PENELITIAN}

\section{Tempat dan Waktu Penelitian}

Penelitian ini dilaksanakan selama 8 bulan. Lokasi Penelitian di Kabupaten Bolaang Mongondow sebagai salah satu daerah sentra produksi kopi di Provinsi Sulawesi Utara.

\section{Metode Pengumpulan Data}

Data yang digunakan meliputi data primer dan data sekunder. Data primer diperoleh dengan teknik wawancara pada petani kopi. Sedangkan data sekunder diambil dari instansiinstansi yang terkait dalam penelitian ini Badan Pusat Staistik dan Dinas Pertanian.

\section{Metode Pengambilan Sampel}

Penentuan lokasi dilakukan secara purposive sampling (sengaja) di salah satu desa di Kecamatan Passi Barat Kabupaten Bolaang Mongondow. Unit analisisnya ditentukan secara acak sederhana (Simple Random Sampling) kepada 20 petani kopi.

\section{Konsep Pengukuran Variabel}

Variabel yang diukur dalam penelitian ini adalah :

1. Karakteristik Petani Kopi

a. Umur (tahun)

b. Tingkat Pendidikan (SD, SMP, SMA dan Perguruan Tinggi)

c. Jumlah Tanggungan

2. Laus lahan yaitu luas lahan yang ditanami kopi oleh petani (Ha)

3. Biaya usahatani yaitu nilai uang yang dipergunakan untuk kegiatan usahatani (Rp)
4. Penerimaan usahatani adalah total produksi dikalikan dengan harga jual yang berlaku (Rp)

5. Keuntungan adalah total penerimaan dikurangi dengan total pengeluaran selama satu periode panen (Rp)

6. Harga Privat adalah harga pasar yang benarbenar diterima dan dikeluarkan petani kopi sebagai produsen dalam usahataninya $(\mathrm{Rp})$

7. Harga Sosial adalah harga yang terjadi pada pasar persaingan sempurna dan akan diukur dengan harga bayangan sosialnya ( $\mathrm{Rp})$

8. Komponen tradeable adalah komponen yang dpat diperdagangkan di pasar internasional seperti Pupuk Urea, KCL dan NPK

9. Komponen nontradeable adalah input produksi yang tidak diperdagangkan di pasar internasional seperti bibit, tenaga kerja dan peralatan

10. Border Price adalah harga per unit suatu barang yang diperdagangkan pada batas suatu negara. Untuk harga barang impor adalah CIF sedangkan untuk harga barang ekspor adalah FOB

11. Shadow Exchange Rate (SER) adalah harga bayangan dari nilai tukar valuta asing.

\section{Metode Analisis Data}

Analisis dampak kebijakan dan keunggulan komparatif dilakukan dengan menggunakan pendekatan model Policy Analysis Matrix (PAM) dengan menghitung :

1. Keuntungan Privat (Private Profitability/PP). $\mathrm{PP}=\mathrm{A}-\mathrm{B}-\mathrm{C}$

2. Keuntungan Sosial (Social Profitability/SP). $\mathrm{SP}=\mathrm{E}-\mathrm{F}-\mathrm{G}$

3. Rasio Biaya Privat (Private Cost Ratio/PCR). $\mathrm{PCR}=\mathrm{C} /(\mathrm{A}-\mathrm{B})$

4. Rasio Biaya Sumberdaya Domestik (Domestic Resources Cost Ratio/DRCR). DRCR=G/ (E-F)

5. Transfer Output (Output Transfer/ OT). $\mathrm{OT}=\mathrm{A}-\mathrm{E}$

6. Koefisien Proteksi Nominal Output (Nominal Protection Coefficient Output/NPCO). NPCO $=\mathrm{A} / \mathrm{E}$

7. Transfer Input (Input Transfer/IT). IT = B-F

8. Koefisien Proteksi Nominal Input (Nominal Protection Coefficient Input/ NPCI). $\mathrm{NPCI}=\mathrm{B} / \mathrm{F}$

9. Transfer Faktor ( Factor Transfer/ FT). $\mathrm{FT}=\mathrm{C}-\mathrm{G}$

10. Transfer Bersih (Net Transfer/NT). NT $=\mathrm{D}-\mathrm{H}$

11. Koefisien Keuntungan (Profitability Coefficient/ PC). $\mathrm{PC}=\mathrm{D} / \mathrm{H}$ 
12. Koefisien Proteksi Efektif (Effective Protection Coefficient/ EPC). EPC $=$ (AB)/(E-F).

13. Rasio Subsidi Produsen (Subsidies Ratio to Producent/ SRP). SRP= L/E.

\section{HASIL DAN PEMBAHASAN}

\section{Gambaran Umum Lokasi Penelitian}

Bolaang Mongondow merupakan salah satu Kabupaten yang ada di Provinsi Sulawesi Utara dengan ibukota Lolak. Secara geografis, Kabupaten Bolaang Mongondow berada di wilayah selatan Provinsi Sulawesi Utara yang terletak antara 0030 ' - 10 0' Lintang Utara dan 1230 - 1240 Bujur Timur. 00 30'. Kabupaten Bolaang Mongondow berbatasan dengan :

- Sebelah Utara dengan Laut Sulawesi.

- Sebelah Selatan dengan Kabupaten Bolaang Mongondow Selatan.

- Sebelah Barat dengan Kabupaten Bolaang Mongondow Utara.

- Sebelah Timur dengan Kota Kotamobagu, Kabupaten Minahasa Selatan dan Kabupaten Bolaang Mongondow Timur.

\section{Karakteristik Responden}

\section{Umur Responden}

Kemampuan petani dalam melaksanakan kegiatan usahatani sangat dipengaruhi oleh kemampuan fisik yang disebabkan karena umur/ usia. Seseorang yang berada pada usia produktif atau usia kerja akan dapat bekerja lebih efisien.

Tabel 1. Data Umur Responden

\begin{tabular}{ccr}
\hline $\begin{array}{c}\text { Kisaran Umur } \\
\text { (Tahun) }\end{array}$ & $\begin{array}{c}\text { Jumlah Responden } \\
\text { (Orang) }\end{array}$ & Persentase (\%) \\
\hline $30-44$ & 6 & 30 \\
$45-59$ & 9 & 45 \\
$60-74$ & 5 & 25 \\
\hline Jumlah & 20 & 100 \\
\hline
\end{tabular}

Sumber : diolah dari data primer, 2019

Tabel 2 menunjukkan bahwa persentase terbesar umur petani berada pada kisaran 45-59 tahun dengan rata- rata umur 53 tahun. Hal ini menunjukkan kemampuan kerja dalam usahatani kopi cukup tinggi karena sebagian besar petani berada pada umur/usia produktif.

\section{Tingkat Pendidikan}

Pendidikan merupakan salah satu faktor dalam menentukan keberhasilan petani. Apabila petani berpendidikan tinggi maka dengan mudah petani dapat dengan mudah menguasai teknologi.

Tabel 2. Tingkat Pendidikan

\begin{tabular}{lcr}
\hline $\begin{array}{c}\text { Tingkat } \\
\text { Pendidikan }\end{array}$ & $\begin{array}{c}\text { Jumlah Responden } \\
\text { (Orang) }\end{array}$ & Persentase (\%) \\
\hline SD & 10 & 50 \\
SMP & 7 & 35 \\
SMA & 3 & 15 \\
\hline Jumlah & 20 & 100 \\
\hline
\end{tabular}

Sumber : diolah dari data primer, 2019

Tabel 2 menunjukkan hasil penelitian dari segi tingkat pendidikan petani responden yang hanya lulus SD memiliki persentase terbesar yaitu $50 \%$. Hal ini menunjukkan bahwa kemampuan petani dalam pengelolaan usahatani kopi masih minim karena penguasaan teknologi masih kurang. Sehingga pengelolaannya masih secara tradisional.

\section{Data Jumlah Tanggungan Keluarga Responden} Jumlah tanggungan keluarga responden dapat dilihat pada Tabel 3.

Tabel 3. Jumlah Tanggungan Keluarga

\begin{tabular}{ccr}
\hline $\begin{array}{c}\text { Jumlah Tanggungan } \\
\text { Keluarga (Orang) }\end{array}$ & $\begin{array}{c}\text { Jumlah Responden } \\
\text { (Orang) }\end{array}$ & Persentase (\%), \\
\hline 4 & 9 & 45 \\
5 & 8 & 40 \\
6 & 3 & 15 \\
\hline Jumlah & 20 & 100 \\
\hline
\end{tabular}

Sumber : diolah dari data primer, 2019

Tabel 3 memunjukkan bahwa petani dengan jumlah tanggungan sebanyak 4 orang adalah yang paling dominan yaitu sebanyak 9 responden dibandingkan dengan yang jumlah tanggungannya 5-6 orang. Ini mengartikan bahwa petani disana turut juga mendukung Program pemerintah dengan Keluarga Kecil Keluarga Bahagia dimana terdiri dari Bapak, Ibu dan 2 orang anak.

\section{Luas Lahan}

Lahan yang dikelola/ dikuasai petani berbeda-beda luasannya, seperti disajikan dalam Tabel 4. 
Tabel 4. Luas Lahan

\begin{tabular}{ccr}
\hline $\begin{array}{c}\text { Luas Lahan } \\
\text { (Hektar) }\end{array}$ & $\begin{array}{c}\text { Jumlah Responden } \\
\text { (Orang) }\end{array}$ & Persentase (\%) \\
\hline 0,25 & 7 & 35 \\
0,5 & 8 & 40 \\
1 & 5 & 25 \\
\hline Jumlah & 20 & 100 \\
\hline
\end{tabular}

Sumber : diolah dari data primer, 2019

Tabel 4 menunjukkan bahwa petani yang memiliki luas lahan 0,5 hektar adalah luas lahan yang paling banyak dikuasai/ dimiliki petani dengan persentase terbesar yaitu $40 \%$ dibandingkan dengan petani yang memiliki luas lahan 0,25 dan 1 hektar. Petani kopi yang ada di Kabupaten Bolaang Mongondow tergolong Petani Kecil karena luas lahannya dibawah dari 1,5 hektar.

\section{Analisis Keunggulan Komparatif}

\section{Analisis biaya privat usahatani Kopi}

Analisis keuntungan finansial mengguna-kan harga privat atau harga aktual yang berlaku di lokasi penelitian sedangkan dalam analisis ekonomi komponen output dan input dinilai menggunakan harga sosial atau harga bayangan. Harga privat lebih tinggi daripada harga sosial yang disebabkan karena harga sosial menggunakan harga bayangan. Pendapatan privat usahatani dapat dilihat pada Tabel 5.

\section{Tabel 5. Analisis Pendapatan Privat} Usahatani Kopi per hektar di Kabupaten Bolaang Mongondow

\begin{tabular}{|c|c|c|}
\hline $\begin{array}{c}\text { Uraian } \\
\text { Tanaman Menghasilkan }\end{array}$ & $\begin{array}{c}\text { Input } \\
\text { Tradeable }\end{array}$ & Biaya (Rp) \\
\hline \multirow[t]{12}{*}{ Tanaman Menghasilkan } & \multicolumn{2}{|l|}{ Tradeable } \\
\hline & \multicolumn{2}{|l|}{ Pupuk } \\
\hline & Urea & 136.875 \\
\hline & SP 36 & 68.437 \\
\hline & $\mathrm{KCl}$ & 65.700 \\
\hline & \multicolumn{2}{|l|}{ Nontradeable } \\
\hline & Tenaga Kerja & \multirow[t]{2}{*}{1.665 .000} \\
\hline & Peralatan & \\
\hline & Pacul & 123.750 \\
\hline & Sekop & 122.500 \\
\hline & Alat Semprot & 3.350 \\
\hline & Parang & 95.500 \\
\hline Amortisasi & \multicolumn{2}{|c|}{21.237} \\
\hline Penerimaan & \multicolumn{2}{|c|}{6.593 .750} \\
\hline Keuntungan & \multicolumn{2}{|c|}{6.572 .513} \\
\hline
\end{tabular}

Tabel 5 menunjukkan bahwa analisis privat, alokasi biaya terbesar pada curahan tenaga kerja yaitu sebesar Rp.1.665.000 dan alokasi biaya terkecil adalah peralatan (alat semprot) yaitu Rp.3.350. Biaya amortisasi sebesar Rp.21.237 dari total penerimaan Rp.6.593.750 sehingga memberikan keuntungan sebesar Rp.6.572.513.

Tabel 6. Matrik Analisis Kebijakan Usahatani Kopi per Hektar di Kabupaten Bolaang Mongondow

\begin{tabular}{lrrrr}
\hline Keterangan & Penerimaan & \multicolumn{2}{c}{ Biaya } & Keuntungan \\
\cline { 3 - 4 } & & Tradeable & $\begin{array}{c}\text { Non } \\
\text { Tradeable }\end{array}$ \\
\hline Harga & 6.593 .7 & 271.012 & 501.148 & 5.821 .5 \\
Privat & 50 & & & 90 \\
Harga & 6.168 .7 & 168.355 & 475.057 & 5.525 .3 \\
Sosial & 50 & & & 38 \\
Dampak & 425.000 & 102.657 & 26.091 & 296.252 \\
Kebijakan & & & \\
\hline \multicolumn{3}{l}{ Sumber : Analisis Data Primer, 2019 }
\end{tabular}

Tabel 6 menunjukkan bahwa penerimaan pada harga privat dan pada harga sosial. Penerimaan pada harga privat Rp. 6.593.750 yang diperoleh dari produksi dikalikan harga jual kopi yang bervariasi antara Rp.22.000 Rp. 25.000 dengan rata- rata Rp.22.800. Penerimaan pada harga sosial Rp. 6.168.750 dengan menggunakan harga jual (harga bayangan) Rp.21.000. Dampak kebijakan merupakan selisih penerimaan harga privat dan penerimaan harga sosial.

Pada biaya tradeable Rp. 271.012 meliputi biaya pupuk pada harga privat menggunakan harga yang benar-benar dikeluarkan oleh petani sedangkan pada harga sosial Rp.168.355 menggunakan harga bayangan pupuk. Demikian juga dengan biaya nontradeable pada harga privat Rp.501.148 dan harga sosial Rp.475.057 meliputi biaya pupuk tenaga kerja dan peralatan. Dampak kebijakan pada biaya tradeable maupun nontradeable merupakan selisih harga privat dan harga sosial.

Keuntungan harga privat Rp. 5.821.590 merupakan selisih antara penerimaan dan biaya tradeable juga nontradeable. Keuntungan pada harga sosial adalah penerimaan menggunakan harga bayangan dan biaya tradeable juga nontradeable.

Secara lengkap hasil perhitungan analisis dampak kebijakan menggunakan Policy Analysis Matrix dapat dilihat pada Tabel 7. 
Tabel 7. Analisis Efisiensi dan Keunggulan Kompar atif

\begin{tabular}{lc}
\hline \multicolumn{1}{c}{ Uraian } & Nilai \\
\hline Private Profitability (PP) & 5.821 .590 \\
Social Profitability (SP) & 5.525 .338 \\
Private Cost Ratio (PCR) & 0,0792 \\
Domestic Resource Cost Ratio (DRCR) & 0,0791 \\
\hline Sumber: Analisis Data Primer, 2019
\end{tabular}

Tabel 7 menunjukkan bahwa didapatkan nilai Private Profitability bertanda positif yaitu Rp. 5.821 .590 artinya berdasarkan parameter keuntungan privat maka usahatani kopi di Kabupaten Bolaang Mongondow layak diusahakan tanpa adanya campur tangan pemerintah dengan tingkat keuntungan sebesar Rp. 5.821.590 per hektar per periode panen.

Dari analisis diperoleh nilai Social Profitability bertanda positif, artinya berdasarkan parameter keuntungan sosial maka usahatani kopi layak diusahakan tanpa ada campur tangan pemerintah dengan tingkat keuntungan sebesar Rp. 5.525.338 per hektar per periode panen.

Dari analisis didapatkan nilai Private Cost Ratio sebesar 0,0792 artinya untuk meningkatkan nilai tambah output sebesar satu satuan pada harga privat diperlukan tambahan biaya input nontradeable sebesar 0,0792 atau kurang dari satu satuan.

Keunggulan komparatif usahatani kopi dianalisis dengan Domestic Resource Cost Ratio. Analisis rasio antara biaya sumberdaya dan nilai tambah yang dihitung dengan harga sosial disebut Domestic Resource Cost (DRC).

Hasil analisis DRCR usahatani kopi diperoleh nilai 0,0791 mengartikan bahwa memproduksi kopi di Kabupaten Bolaang Mongondow efisien, dan kondisi ini mencerminkan bahwa usahatani kopi memiliki keunggulan komparatif.

\section{Analis is Kebijakan Di Bidang Output}

Tabel 8 menunjukkan bahwa hasil analisis menunjukkan nilai Output Transfer bertanda positif yaitu Rp.425.000, artinya ada campur tangan pemerintah yang menguntungkan petani kopi di Kabupaten Bolaang Mongondow.
Hasil analisis didapatkan nilai NPCO lebih besar dari 1 atau sebesar 1,068. Hal ini menunjukkan bahwa produsen kopi mendapatkan proteksi harga. Kebijakan pemerintah telah menjadikan harga yang diterima produsen kopi lebih tinggi dari harga bayangan (harga yang berlaku dipasar internasional). Ini berarti kebijakan menguntungkan pihak petani sebagai produsen kopi.

Tabel 8. Nilai Parameter Dampak Kebijakan Pemerintah di bidang output

\begin{tabular}{lr}
\hline \multicolumn{1}{c}{ Uraian } & Nilai (Rp) \\
\hline Output Transfer (OT) & 425.000 \\
Nominal Protection Coefficient Output (NPCO) & 1,068 \\
\hline Sumber : Analisis Data Primer, 2019
\end{tabular}

\section{Analisis Kebijakan Di Bidang Input}

Analisis Policy Analysis Matrix, dampak kebijakan pemerintah terhadap faktor domestik dapat dilihat dari besarnya nilai Factor Transfer (FT) sedangkan terhadap input tradeable dapat dilihat dari besarnya nilai Input Transfer (IT). Sedangkan untuk mengetahui besarnya dampak kebijakan pemerintah tersebut dapat diketahui dari nilai Nominal Protection Coefficient Input (NPCI). Dapat dilihat pada Tabel 9.

Tabel 9. Nilai Parameter Dampak Kebijakan Pemerintah di bidang Input

\begin{tabular}{lc}
\hline \multicolumn{1}{c}{ Uraian } & Nilai \\
\hline Factor Transfer $(F T)$ & 26.091 \\
Nominal Protection Coefficient Input (NPCI) & 1,609 \\
Input Transfer $(I T)$ & 102,657 \\
\hline Sumber: Analisis Data Primer, 2019
\end{tabular}

Tabel 9 menunjukkan bahwa hasil analisis menunjukkan nilai Output Transfer bertanda positif yaitu Rp.425.000, artinya ada campur tangan pemerintah yang menguntungkan petani kopi di Kabupaten Bolaang Mongondow.

Hasil analisis didapatkan nilai NPCO lebih besar dari 1 atau sebesar 1,068. Hal ini menunjukkan bahwa produsen kopi mendapatkan proteksi harga. Kebijakan pemerintah telah menjadikan harga yang diterima produsen kopi lebih tinggi dari harga bayangan (harga yang berlaku dipasar internasional). Ini berarti kebijakan menguntungkan pihak petani sebagai produsen kopi. 


\section{Analisis Kebijakan Di Bidang Input}

Analisis Policy Analysis Matrix, dampak kebijakan pemerintah terhadap faktor domestik dapat dilihat dari besarnya nilai Factor Transfer (FT) sedangkan terhadap input tradeable dapat dilihat dari besarnya nilai Input Transfer (IT). Sedangkan untuk mengetahui besarnya dampak kebijakan pemerintah tersebut dapat diketahui dari nilai Nominal Protection Coefficient Input (NPCI).

Tabel 11. Nilai Parameter Dampak Kebijakan Pemerintah di bidang Input

\begin{tabular}{lc}
\hline \multicolumn{1}{c}{ Uraian } & Nilai \\
\hline Factor Transfer (FT) & 26.091 \\
Nominal Protection Coefficient Input (NPCI) & 1,609 \\
Input Transfer (IT) & 102,657 \\
\hline Sumber: Analisis Data Primer, 2019
\end{tabular}

Distorsi kebijakan pemerintah pada input nontradeable ditunjukkan dengan nilai factor transfer. Factor transfer sama dengan pengertian input transfer, yang membedakan adalah jika input transfer mencerminkan selisih input tradeable, sedangkan factor transfer mencerminkan penggunaan faktor input nontradeable. Factor transfer adalah biaya nontradeable privat dikurangi biaya nontradeable sosial.

Dari hasil analisis didapatkan nilai factor transfer bertanda positif 26,091. Artinya bahwa kebijakan pemerintah menguntungkan produsen input nontradeable atau input domestik yang menyebabkan para petani kopi membayar harga input nontradeable lebih mahal dari harga sesungguhnya jika terjadi pada pasar persaingan sempurna. Ini terjadi karena adanya perbedaan penerapan upah tenaga kerja dan pajak lahan yang harus dibayar.

Dari analisis diperoleh nilai positif yaitu Nominal Protection Coefficient Input sebesar 1,609. Hal ini menunjukkan bahwa penerapan tarif impor pada beberapa input tradeable menyebabkan kenaikan harga input tradeable dipasar. Selain input tradeable, petani kopi juga menggunakan input nontradeable yang tidak diperdagangkan dipasar dunia. Besaran yang menunjukkan perbedaan antara harga sosial dengan harga sesungguhnya yang diterima produsen untuk pembayaran faktor produksi yang nontradeable disebut transfer factor.
Dari analisis didapatkan nilai input transfer bertanda positif 102,657. Hal itu menunjukkan bahwa produsen kopi tidak mendapat subsidi harga input tradeable dari pemerintah sebesar Rp. 102,657. Petani membayar input tradeable lebih mahal dari harga yang sebenarnya.

Tabel 12. Analisis Kebijakan Di Bidang Input Output

\begin{tabular}{lr}
\hline \multicolumn{1}{c}{ Uraian } & Nilai \\
\hline Net Transfer (NT) & Rp. 296.252 \\
Profitability Cofficient (PC) & 1,053 \\
Effective Protection Coefficient (EPC) & 1,054 \\
Subsidies Ratio to Producent (SRP) & 0,048 \\
\hline Sumber : Analisis Data Primer, 2019
\end{tabular}

Dari analisis didapatkan nilai $\mathrm{Net}$ Transfer positif Rp. Rp. 296.252. Ini berarti bahwa kebijakan pemerintah (baik terhadap input maupun output) menyebabkan petani kopi mendapat kebijakan surplus atau terjadi transfer pemerintah ke produsen kopi di Kabupaten Bolaang Mongondow sebesar Rp. Rp. 296.252. Hal ini juga mengindikasikan walaupun komoditas kopi yang diusahakan petani terjadi surplus atau memliki keunggulan namun tetap memerlukan proteksi dari pemerintah sehingga petani kopi tetap mau berproduksi, karena apabila tidak ada rangsangan yang diterima petani, tidak tertutup kemungkinan petani kopi akan beralih ke komoditas lain yang lebih menguntungkan.

Dari analisis didapatkan nilai Profitability Coefficient $=1,053$. Ini menunjukkan bahwa keuntungan yang diterima petani kopi lebih besar dari keuntungan sosial.

Hasil analisis menunjukkan nilai Effective Protection Coefficient $>1$ yaitu 1,054. Terdapat kebijakan pemerintah terhadap harga output maupun subsidi terhadap input bersifat efektif melindungi petani kopi. Proteksi tersebut dapat berupa hambatan perdagangan (pajak retribusi terhadap input maupun output yang masuk atau keluar dari Kabupaten Bolaang Mongondow). 
Subsidies Ratio to Producent (SRP) merupakan persentase rasio antar transfer bersih dengan penerimaan sosial (L/E). Rasio ini menunjukkan proporsi transfer terhadap nilai output kebijakan pemerintah atau penambahan/ pengurangan penerimaan karena adanya kebijakan pemerintah. Subsidies Ratio to Producent lebih kecil dari nol menunjukkan bahwa petani kopi mengeluarkan biaya produksi lebih besar dari imbangan berproduksi dibanding bila tidak ada campur tangan pemerintah atau distorsi pasar dan sebaliknya bila Subsidies Ratio to Producent lebih besar dari nol (positif).

Hasil analisis didapatkan nilai Subsidies Ratio to Producent lebih besar dari nol yaitu sebesar 0,048. Artinya dengan adanya kebijakan pemerintah, produsen kopi membayar biaya produksi lebih rendah dari biaya imbangan berproduksinya (opportunity cost). Kebijakan pemerintah seperti adanya subsidi harga input dan proteksi perdagangan, sebenarnya menguntungkan bagi pengembangan dan peningkatan produksi usahatani kopi di Kabupaten Bolaang Mongondow.

\section{KESIMPULAN DAN SARAN}

\section{Kesimpulan}

Berdasarkan hasil penelitian tentang pengaruh nilai jual objek pajak, luas kepemilikan tanah, dan mata pencaharian terhadap nilai ganti rugi tanah pada pembangunan Manado outer Ring Road III, peneliti mengambil kesimpulan sebagai berikut :

1. Nilai Domestic Return Cost Ratio (DRCR) usahatani kopi sebesar 0,0791 mengartikan bahwa usahatani kopi di Kabupaten Bolaang Mongondow memiliki keunggulan komparatif dan efisien secara ekonomi dalam pemanfaatan sumber daya domestik
2. Secara privat dan sosial kopi memiliki keunggulan komparatif, hal ini dapat dilihat dari nilai Domestic Return Cost Ratio (DRCR) dan Private Cost Ratio (PCR) kurang dari 1. Nilai DRCR menunjukkan bahwa dengan memproduksi sendiri kopi akan lebih menguntungkan daripada mengimpor.

3. Secara privat usahatani kopi memiiki nilai Private Profitability (PP) sebesar dan secara ekonomi memiliki nilai Social Profitability (SP) sebesar artinya layak untuk diusahakan tanpa adanya campur tangan pemerintah dan masih memiliki keunggulan komparatif.

\section{Saran}

1. Diperlukan kebijakan pemerintah untuk melindungi petani kopi agar menerima manfaat dari adanya kebijakan itu sehingga dapat menguntungkan produsen kopi yang meliputi perlindungan harga kopi

2. Adanya pelatihan bagi para petani dalam penggunaan teknologi agar lebih efektif dan efisien untuk menjalankan kegiatan usahatani kopi sehingga dapat meningkatkan keuntungan yang lebih maksimal.

\section{DAFTAR PUSTAKA}

Soetriono, Ariel. H. 2010. Daya Saing Kopi Robusta di Pasar Internasional. Jurnal Sosial Ekonomi Pertanian Vol.4 No.2. Program studi Agribisnis Pasca Sarjana. Universitas Jember. 